\title{
Extent of adoption of home science practices disseminated under Rural Awareness Work Experience (RAWE)
}

\author{
Sandeep Kaur and Sukhdeep Kaur Mann
}

Received: 23.01.2020; Revised: 05.03.2020; Accepted: 19.04.2020

See end of the paper for authors' affiliations Sandeep Kaur Department of Extension Education and Communication Management, Punjab Agricultural University, Ludhiana (Punjab) India

Email : sandeepbhullar586@ gmail.com
ABSTRACT : Rural Awareness Work Experience (RAWE) was introduced in to the curriculum of B.Sc. Home Science (Hons.) by Indian Council of Agricultural Research (ICAR), New Delhi, in the year 2002. It aims at bringing improvement in quality of life of rural families. It had also been realized that formal system of education is restricted to classroom and laboratory situation. In real life situation learning through experience has become an integral part of the education. This informal education enables the students and teachers to actively participate in examining the subject matter and it's utility to solve problems of the rural women. The present study was planned to assess the extent of adoption of home science practices disseminated under Rural Awareness Work Experience (RAWE) programme of College of Home Science, Punjab Agricultural University (PAU), Ludhiana. Four villages i.e. Rauwal, Sidhwan Kalan, Talwandi Khurd and Sarabha of Ludhiana district were selected for the purpose of the study. A total of 120 rural women constituted the sample of the study. The findings of the study inferred that the extent of adoption of majority of respondents for Apparel and Textile Science (77.50\%) and Family Resource Management (74.16\%) was low. Consequently, it may be concluded that there is a large scope for betterment of adoption rate of home science practices by rural women.

KEY WORDS: RAWE, Extent of adoption, Rural women

- HOW TO CITE THIS PAPER : Kaur, Sandeep and Mann, Sukhdeep Kaur (2020). Extent of adoption of home science practices disseminated under Rural Awareness Work Experience (RAWE). Asian J. Home Sci., 15 (1) : 21-26, DOI: 10.15740/HAS/AJHS/15.1/21-26. Copyright@ 2020: Hind Agri-Horticultural Society. 